\title{
KEEFEKTIFAN MANAJEMEN PROGRAM PEMBELAJARAN BIPA (BAHASA INDONESIA BAGI PENUTUR ASING) DI KOTA YOGYAKARTA
}

\author{
Ekaresta Prihardjati Saputro, Suharsimi Arikunto \\ Prodi Manajemen Pendidikan PPs UNY, Universitas Negeri Yogyakarta \\ agataekaresta@ymail.com
}

\begin{abstract}
Abstrak
Penelitian ini bertujuan untuk mengevaluasi manajemen program pembelajaran BIPA di lembaga BIPA Kota Yogyakarta. Penelitian ini merupakan penelitian evaluasi dengan pendekatan kombinasi kualitatif dan kuantitatif. Model evaluasi yang digunakan adalah discrepancy evaluation model. Hasil penelitian menunjukkan bahwa implementasi manajemen program pembelajaran BIPA (1) aspek perencanaan program mencapai 93\%, kesenjangan $7 \%$ dengan kriteria "sangat efektif"; (2) aspek pengorganisasian program mencapai 99\%, kesenjangan 1\% dengan kriteria "sangat efektif"; (3) aspek pelaksanaan program mencapai 93\%, kesenjangan 7\% dengan kriteria "sangat efektif"; (4) aspek pengawasan program mencapai $86 \%$, kesenjangan $14 \%$ dengan kriteria "sangat efektif". Secara keseluruhan keefektifan manajemen program pembelajaran BIPA memiliki kriteria "sangat efektif", dengan capaian $93 \%$ kesenjangan $7 \%$.
\end{abstract}

Kata kunci: evaluasi; keefektifan; manajemen program pembelajaran BIPA

\section{THE EFFECTIVENESS OF BIPA (INDONESIAN LANGUAGE FOR FOREIGNER) PROGRAM MANAGEMENT IN YOGYAKARTA}

\author{
Ekaresta Prihardjati Saputro, Suharsimi Arikunto \\ Prodi Manajemen Pendidikan PPs UNY, Universitas Negeri Yogyakarta \\ agataekaresta@ymail.com
}

\begin{abstract}
This study is aimed to evaluate the management of BIPA learning program of BIPA course in Yogyakarta. This research is an evaluation research with the combination of qualitative and quantitative approach. Evaluation model used in this research is discrepancy evaluation model. The result of the study shows that the implementation of the management of BIPA learning program (1) the planning program is 93\% performance, 7\% discrepancy with criteria "very effective"; (2) the organizing aspect is $99 \%$ performance and 1\% discrepancy with criteria "very effective"; (3) the implementing aspect is 93\% performance and 7\% discrepancy with criteria "very effective"; (4) the monitoring aspect is $86 \%$ performance $14 \%$ discrepancy with criteria "very effective". After all the effectiveness of the management of BIPA learning program have "very effective" criteria, with 93\% performance and $7 \%$ discrepancy.
\end{abstract}

Keywords: evaluation, the effectiveness, BIPA program management 


\section{Pendahuluan}

Indonesia merupakan salah satu negara di kawasan Asia Tenggara dengan posisi geografis yang sangat strategis. Dengan adanya MEA (Masyarakat Ekonomi Asean) siapa saja bebas mengalirkan barang, jasa, investasi, permodalan, dan tenaga kerja ke wilayah Indonesia. Sejalan dengan mengalirnya barang dan jasa dari dan ke luar negeri, kedudukan bahasa Indonesia semakin penting. Bagi orang asing yang memiliki kepentingan di Indonesia selayaknya mereka mampu berbahasa Indonesia. Keputusan Menteri Tenaga Kerja dan Transmigrasi RI Nomor 20 Tahun 2004 mengatur tentang tata cara memperoleh izin mempekerjakan tenaga kerja asing. Pada bab II pasal 2 ayat (1) menyebutkan bahwa tenaga kerja asing yang akan bekerja di Indonesia wajib berkomunikasi dalam bahasa Indonesia. Selain itu, terkait dengan ketenagakerjaan bahwa dokumen kerja atau perjanjian kerja harus dalam bahasa Indonesia. Perjanjian kerja yang melibatkan tenaga kerja asing (TKA) harus menggunakan bahasa Indonesia berimplikasi bahwa TKA harus memahami isi perjanjian tersebut. Untuk itu, TKA diberi ruang untuk mempelajari bahasa Indonesia.

Dari beberapa fakta di atas, tuntutan bahasa Indonesia sebagai bahasa internasional semakin mendesak untuk diupayakan. Upaya tersebut bisa diwujudkan dengan pengembangan Bahasa Indonesia bagi Penutur Asing (BIPA). Pengembanganan BIPA akan membantu visi pemerintah untuk meningkatkan bahasa Indonesia menjadi bahasa internasional. Baik di Indonesia maupun di luar negeri pembukaan kursuskursus Bahasa Indonesia bagi Penutur Asing semakin marak diselenggarakan.

Program BIPA merupakan program pendidikan nonformal yang diselenggarakan bagi orang asing yang ingin mempelajari bahasa Indonesia dengan tujuan khusus. Pendidikan nonformal menurut Combs \& Ahmed (1985, p. 10) adalah "setiap kegiatan pendidikan yang terorganisir dan sistematis, diselenggarakan di luar sistem pendidikan formal dengan maksud memberikan layanan khusus bagi warga belajar guna membantu mengidentifikasi kebutuhan belajar dan mencapai tujuan belajarnya". Dengan karakteristik tersebut pengelola BIPA berusaha menemukan desain pengelolaan program yang benarbenar efektif dan sesuai untuk mencapai target belajar murid.

Berdasarkan penelitian Suyitno (2007, p. 76) yang berjudul "Pengembangan Bahan Ajar BIPA Berdasarkan Hasil Analisis Kebutuhan Belajar" menunjukkan bahwa pelajar BIPA adalah pelajar yang memiliki latar belakang budaya, tujuan belajar, dan bidang keahlian yang beragam. Oleh sebab itu, pengelola lembaga BIPA hendaknya mampu mengelola program dengan memperhatikan faktor diri pembelajar.

Pengelolaan program merupakan implementasi dari fungsi-fungsi manajemen. Program pembelajaran BIPA perlu dikelola dan dikembangkan dengan baik untuk mendukung visi pemerintah. Pengembangan program pembelajaran BIPA bisa dimulai dengan mengimplementasikan manajemen program pembelajaran yang efektif. Daft (1991, p. 5) mengartikan konsep manajemen sebagai "... the attainment of organizational goals in an effective and efficient manner through planning, organizing, leading, and controlling organizational resources". Dalam pengertian tersebut mengandung dua hal penting, yang pertama bahwa terdapat empat fungsi dalam manajemen, yaitu perencanaan, pengorganisasian, pembinaan, dan pengendalian. Kedua, bahwa pencapaian tujuan organisasi dilakukan secara efektif dan efisien. Daft (1991, p. 11) menyebutkan bahwa "Effectiveness is the degree of which the organization achiever a started objective" yang berarti bahwa keefektifan adalah tingkatan dalam organisasi untuk mencapai tujuan yang telah ditetapkan. Keefektifan sebuah organisasi terlaksana jika hasil yang diperoleh sesuai dengan tujuan/target/standar yang ditetapkan.

Berdasarkan hasil penelusuran, belum pernah dilaksanakan penelitian terkait dengan manajemen program pembelajaran BIPA. Oleh sebab itu, penelitian ini mengarah kepada evaluasi manajemen program BIPA. Aspek manajemen yang dimaksud 
adalah perencanaan, pengorganisasian, pelaksanaan, dan pengawasan program.

Evaluasi manajemen program BIPA akan dilaksanakan di lembaga kursus BIPA di kota Yogyakarta yang menerapkan metode langsung (bukan terjemahan). Berdasarkan hasil pra-observasi, ditentukan dua lembaga yang dinyatakan sebagai lokasi penelitian. Untuk menjaga kerahasiaan sumber selanjutnya dalam penelitian ini, lembaga tersebut akan disebut lembaga A dan lembaga B.

Evaluasi manajemen program pembelajaran BIPA penting dilakukan untuk mengumpulkan data mengenai kondisi nyata sesuatu hal, sejauh mana, dalam hal apa, dan bagian mana tujuan yang sudah tercapai. Hasil evaluasi akan menemukan kelebihan dan kelemahan program. Kelemahan dan kelebihan program tersebut dianalisis dan dicari solusinya untuk menemukan sebuah rekomendasi bagi manajemen program pembelajaran BIPA yang efektif.

Worthen \& Sanders (1980, p. 19), memberikan pendapat tentang definisi evaluasi sebagai berikut "Evaluation is the determination of the worth of a thing. It includes information for use in judging the worth of the potential utility of alternative approaches designed to attain specified objectives". Pernyataan tersebut mengimplikasikan adanya standar atau kriteria tertentu yang digunakan untuk menentukan nilai. Kriteria yang digunakan dalam penelitian ini salah satunya berasal dari penelitianpenelitian yang relevan terkait program pembelajaran BIPA.

Penelitian yang sudah dilaksanakan selama ini menggambarkan tentang program pembelajaran BIPA secara umum. Seperti penelitian yang dilakukan oleh Pusat Bahasa (2010) di 14 universitas di Asia yang berjudul "Pemetaan Pengajaran bahasa Indonesia bagi Penutur Asing (BIPA) di Asia. Dalam penelitian ini diketahui tentang data awal kondisi pembelajaran BIPA yang mencakup lembaga, pembelajar, pengajar, sarana dan prasarana, dan dana pembelajaran.
Penelitian berikutnya terkait dengan evaluasi pembelajaran BIPA yang dilakukan oleh Rosidi (2012) yang berjudul "Prosedur dan Teknik Evaluasi Pembelajaran bahasa Indonesia sebagai Bahasa Asing". Dari penelitian ini diperoleh informasi cara melaksanakan evaluasi pembelajaran BIPA. Selain itu, standar/kriteria juga bersumber dari sumber ketiga menurut Arikunto \& Jabar (2009, p. 35) adalah petunjuk pelaksanaan program dari masing-masing lembaga yang disesuaikan dengan konsep-konsep dalam pembelajaran BIPA, teori-teori pembelajaran bahasa kedua, dan teori-teori manajemen program.

\section{Metode Penelitian}

Jenis penelitian yang digunakan dalam penelitian ini adalah penelitian evaluasi dengan metode kombinasi (mixed method) dengan desain concurent triangulation. Selain sebagai rekomendasi terhadap pengambil keputusan, penelitian ini juga memperkaya pengetahuan tentang standar penerapan manajemen program pembelajaran BIPA di lembaga kursus, khususnya yang menerapkan pembelajaran BIPA dengan metode langsung. Model evaluasi yang digunakan dalam penelitian ini adalah discrepancy evaluation model yang dikembangkan oleh Malcolm Provus.

Tempat penelitian ini adalah lembaga kursus BIPA kota Yogyakarta. Waktu penelitian ini dilakukan selama 4 bulan yaitu bulan September 2015-Desember 2015. Subjek penelitian ini adalah kepala bagian kurikulum dan kepala bagian pengajaran, koordinator kelas dan murid. Subjek penelitian dipilih dengan metode purposive sampling, berdasarkan tingkat kelas yang diselenggarakan di setiap lembaga kursus BIPA.

Data penelitian ini berupa data kualitatif dan data kuantitatif. Data kualitatif dikumpulkan menggunakan pencermatan dokumen, observasi, dan wawancara. Pedoman wawancara ditujukan kepada kepala bagian pengajaran dan koordinator kelas terkait dengan aspek manajemen yang selama ini dilakukan. Pencermatan dokumen dilakukan dengan menganalisis doku- 
men berdasarkan pedoman pencermatan dokumen yang sudah disiapkan sebelumnya. Pencermatan dokumen yang digunakan menggunakan skala 4 . Teknik observasi digunakan untuk mencermati sikap, tindakan, aktivitas dalam mengerjakan tugas sesuai peran dan fungsi yang dilakukan oleh kepala bagian pengajaran, koordinator kelas, dan guru selama menjalankan fungsi-fungsi manajemen.

Data Kuantitatif dikumpulkan menggunakan angket dengan skala Guttman. Angket ditujukan kepada murid lembaga kursus BIPA. Angket berfungsi untuk mengukur ketercapaian manajemen program pembelajaran BIPA dari sisi murid. Penyusunan instrumen berupa pencermatan dokumen, pedoman observasi, dan angket berpedoman pada juklak program BIPA yang telah disusun oleh lembaga, teori-teori pembelajaran bahasa kedua, dan teori-teori manajemen program.

Analisis data dilakukan dengan memisahkan data hasil kualitatif dan data hasil kuantitatif. Data kualitatif dianalisis dengan model analisis interaktif, Miles \& Huberman (1994). Dalam penelitian ini data kuantitatif yang diperoleh dianalisis dengan teknik deskriptif persentase. Adapun langkah-langkah dalam memberikan nilai dilakukan dengan cara memberikan penilaian terhadap setiap ketercapaian indikator pelaksanaan program dengan skor 1 (satu) untuk setiap skor yang dilaksanakan, skor nol (0) untuk indikator pelaksanaan program yang tidak dilaksanakan. Selanjutnya menghitung persentase ketercapaian dengan menjumlahkan kinerja yang dilaksanakan, kemudian dibagi dengan jumlah seluruh kriteria pelaksanaan program sesuai dengan standarnya, kemudian dikalikan 100.

Guna mengetahui data hasil konversi kuantitatif ke kualitatif digunakan kriteria kuantitatif tanpa pertimbangan dari Arikunto \& Jabar (2014, p. 35) seperti Tabel 1.

Kesimpulan hasil data kualitatif dan kuantitatif selanjutnya diamati bersamaan sehingga menghasilkan meta analisis. Dari hasil meta analisis diperoleh kesimpulan apakah kedua data saling memperkuat, memperlemah atau bertentangan.

Tabel 1. Konversi Data Kuantitatif ke Data Kualitatif Tanpa Pertimbangan

\begin{tabular}{cc}
\hline Interval Skor & Data Kualitatif \\
\hline $81 \%-100 \%$ & Sangat efektif \\
$61 \%-80 \%$ & Efektif \\
$41 \%-60 \%$ & Cukup \\
$21 \%-40 \%$ & Kurang \\
$<21 \%$ & Sangat Kurang \\
\hline
\end{tabular}

\section{Hasil Penelitian dan Pembahasan}

Gambaran manajemen program pembelajaran BIPA di lembaga kursus BIPA kota Yogyakarta adalah sebagai berikut. Lembaga BIPA menawarkan program kursus bahasa Indonesia bagi orang asing. Tidak hanya belajar bahasa, melainkan juga mempelajari budaya Indonesia. Manajemen pembelajaran didesain agar murid dapat menguasai bahasa Indonesia secara wajar dan bisa menggunakannya dalam kehidupan sehari-hari. Program pembelajaran merupakan implementasi dari kurikulum yang dirancang berdasarkan kebutuhan murid. Guna menjamin keotentikan kurikulum, lembaga juga menjadikan kurikulum internasional BIPA dari Amerika, Australia dan Eropa sebagai referensi. Kurikulum disajikan dalam buku materi yang disediakan per level, mulai dari level beginner sampai dengan advance. Tim materi selalu melakukan berbagai evaluasi dan revisi untuk membuat program sesuai dengan kebutuhan murid.

Dari kurikulum, tim membuat buku ajar. Buku ajar disediakan sesuai program belajar yang ditawarkan. Secara umum, pembelajaran dimulai dengan mengenalkan konsep dalam bahasa Indonesia menggunakan berbagai media pembelajaran dan ilustrasi, melatihkan konsep dengan pengulangan, menghadirkan situasi ke dalam kelas, dan membawa murid ke luar. Dengan menggunakan metode langsung, murid dilatih berfikir dalam bahasa Indonesia, menganalisa, dan mengindentifikasi pola kalimat dalam bahasa Indonesia. Dengan melakukan identifikasi murid menemukan 
ide-ide dan pola-pola kalimat dalam bahasa Indonesia.

Pembelajaran di dalam kelas dilaksanakan dengan komposisi 1:4. Setiap murid dalam satu kelas mendapatkan maksimal 4-5 guru. Setiap sesi, murid akan diajar oleh satu guru. Hal ini dimaksudkan agar peserta didik terbiasa dengan berbagai gaya berbicara, intonasi, kecepatan dan artikulasi.

Keefektifan Perencanaan Program Pembelajaran BIPA di Lembaga Kursus BIPA Kota Yogyakarta

Data hasil penelitian pada aspek perencanaan program pembelajaran BIPA dari data hasil kualitatif menunjukkan kriteria "sangat efektif". Hal tersebut dikuatkan dengan data hasil kuantitatif yang menunjukkan kriteria "sangat efektif". Aspek perencanaan program pembelajaran BIPA sudah berjalan "sangat efektif" dengan pencapaian $93 \%$.

Perencanaan program didukung oleh lima capaian kegiatan yaitu rancangan kurikulum yang mencapai $89 \%$, rancangan pembelajaran yang mencapai $91 \%$, rancangan strategi yang mencapai $97 \%$, rancangan evaluasi yang mencapai $81 \%$, dan pemahaman koordinator terhadap kebutuhan murid mencapai $100 \%$.

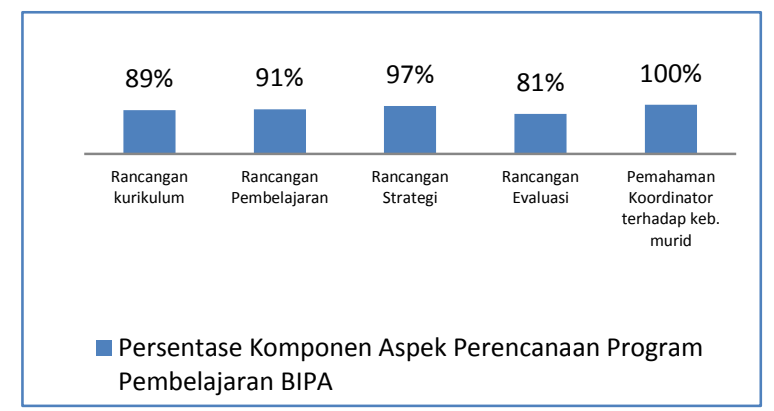

Gambar 1. Grafik Persentase Komponen Aspek Perencanaan Program Pembelajaran BIPA

Lembaga kursus BIPA melakukan kegiatan perencanaan program dimulai dengan merancang kurikulum. Rancangan kurikulum meliputi keberadaan dokumen silabus yang mencapai $81 \%$; RPP (lesson plan) yang mencapai $86 \%$; SOP program yang mencapai $100 \%$.

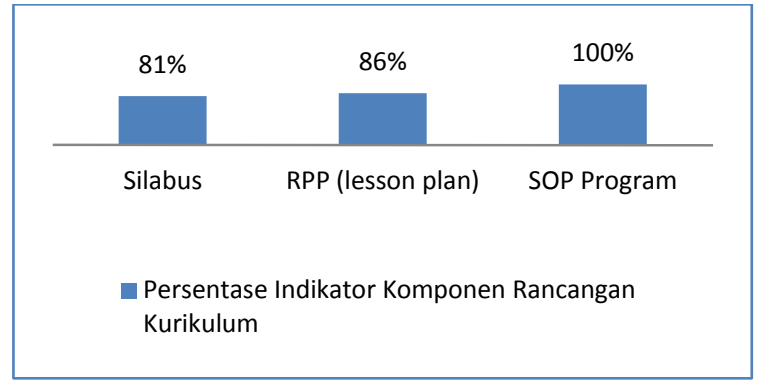

Gambar 2. Grafik Persentase Indikator Rancangan Kurikulum

Kurikulum dirancang berdasarkan kebutuhan belajar murid. Lembaga melalui koordinator kelas melakukan analisis kebutuhan murid dan memastikan tujuan belajarnya. Hal ini tepat, sesuai hasil penelitian yang dilakukan oleh Toci (2014, p. 121) berkaitan dengan manfaat analisis kebutuhan pada permulaan kursus" ... if teachers do not carry out needs analysis at the beginning of the course, meeting students language learning preferences will result in failure".

Selanjutnya koordinator membuat rancangan pembelajaran berupa desain silabus atau biasa disebut clipboard. Berdasarkan hasil pengamatan, pencapaian komponen rancangan pembelajaran didukung dengan lima capaian kegiatan yaitu koordinator kelas menuliskan data murid yang mencapai 100\%; menentukan tujuan khusus pembelajaran yang mencapai $88 \%$; menentukan skenario pembelajaran yang mencapai $69 \%$; mengembangkan dan mengorganisasikan materi ajar yang mencapai $100 \%$; memilih sumber belajar yang mencapai $100 \%$.

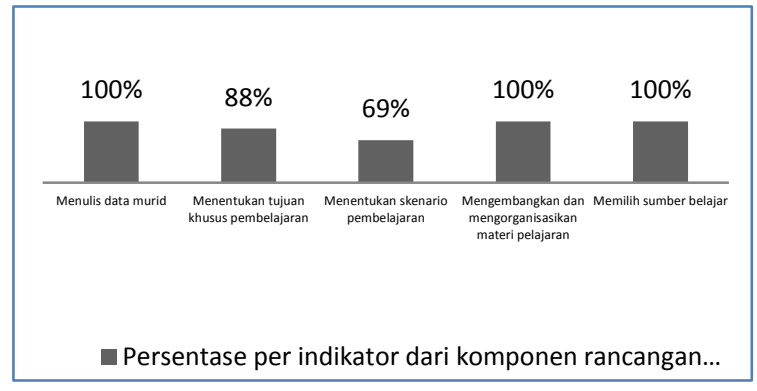

Gambar 3. Grafik Persentase Indikator Komponen Rancangan Pembelajaran

Data murid penting dilengkapi oleh koordinator kelas agar tim guru mendapat- 
kan informasi tentang murid, tujuan belajar, dan permintaan khusus yang diminta. Hal ini penting diketahui koordinator kelas sejak awal sebagai bahan untuk mendesain pembelajaran. Seperti yang diungkapkan oleh Borich (2007, p. 112) bahwa "Planning with respect to your learners begins by conciously noting their unique abilities and experiences that can provide you the opportunity to select content, materials, objectives, and methods that match their current level of understanding and meet their special learning needs".

Aspek perencanaan program selanjutnya dilaksanakan dengan merancang strategi yang termuat dalam desain silabus/clipboard. Berdasarkan hasil pengamatan, pencapaian komponen rancangan strategis didukung dengan dua capaian kegiatan yaitu menentukan metode belajar mencapai rata-rata $92 \%$ dan menentukan media pembelajaran mencapai rata-rata $100 \%$.

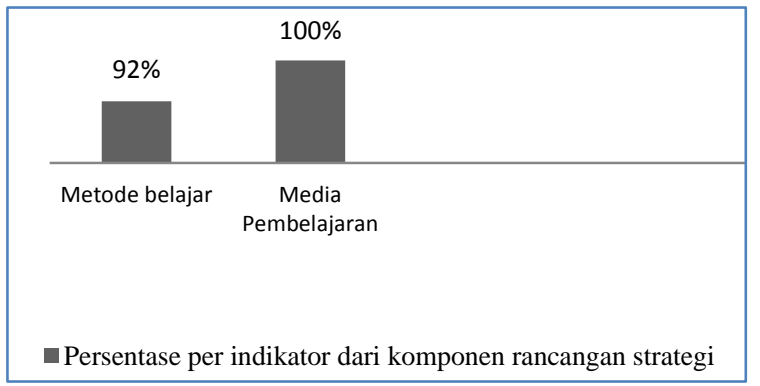

Gambar 4. Grafik Persentase Indikator Komponen Rancangan Strategi

Dalam menentukan metode belajar koordinator kelas dan guru sudah memperhatikan minimal tiga dari empat aspek yang diungkapkan oleh Madya (2013, p. 38) yaitu metode belajar sesuai karakteristik siswa, metode belajar membantu siswa belajar aktif, metode belajar mengasah keempat keterampilan berbicara, metode belajar sesuai dengan materi dan tujuan yang akan dicapai. Dalam menentukan media pembelajaran koordinator dan guru sudah menampilkan lima sampai enam deskriptor seperti yang diungkapkan Suyitno (2007, p. 65) bahwa "media pembelajaran hendaknya sesuai dengan kemampuan siswa, media pembelajaran sesuai dengan tujuan siswa, media pembelajaran jelas dan guru bisa menggunakannya, media pem- belajaran membuat siswa belajar aktif, media pembelajaran mengkongkritkan konsep materi, media pembelajaran menarik dan memotivasi belajar siswa".

Koordinator kelas juga merancang evaluasi. Rancangan evaluasi mencakup indikator menentukan prosedur dan jenis penilaian yang mencapai rata-rata $66 \%$ dan membuat alat penilaian dan kunci jawaban yang mencapai rata-rata $100 \%$.

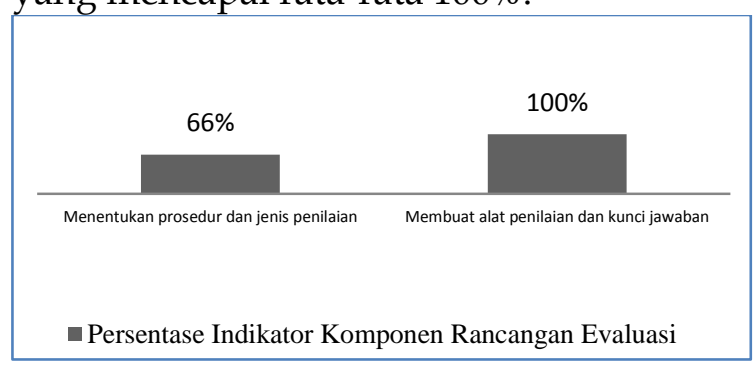

Gambar 5. Grafik Persentase Indikator Komponen Rancangan Evaluasi

Evaluasi yang sering dilakukan oleh guru adalah evaluasi proses. Evaluasi proses dilaksanakan sesudah tahap pengedrilan. Selain itu, Penentuan prosedur dilakukan dengan mencantumkan minimal 1 prosedur dan minimal 1 jenis penilaian tetapi tidak jelas. Pelaksanaan dan teknik dalam evaluasi proses lebih diserahkan pada guru di dalam kelas. Dengan pemahaman tersebut, lebih tepat jika penentuan evaluasi proses dilaksanakan langsung oleh gu$\mathrm{ru}$, tanpa sebelumnya harus dirancang.

Alat penilaian yang diamati adalah bank soal dan latihan yang terdapat dalam buku ajar. Dari pembuatan alat penilaian, rumusan pertanyaan sudah mengukur ketercapaian tujuan pembelajaran dan memenuhi syarat-syarat penyusunan alat evaluasi termasuk penggunaan bahasa yang efektif disertai pencantuman kunci jawaban.

Berdasarkan angket murid, koordinator kelas sudah menyusun materi sesuai kebutuhan murid. Indikator yang dipersyaratkan adalah koordinator menyusun materi sesuai kebutuhan murid mencapai $100 \%$; setiap materi disajikan mengarah pada pencapaian target murid mencapai $100 \%$; murid termotivasi pada setiap materi yang disajikan mencapai $100 \%$; koordinator terbuka pada setiap masukan ma- 
teri mencapai $100 \%$; koordinator memperhatikan perkembangan belajar mencapai $100 \%$; koordinator memperhatikan kebutuhan murid baik selama belajar maupun di luar mencapai $100 \%$.

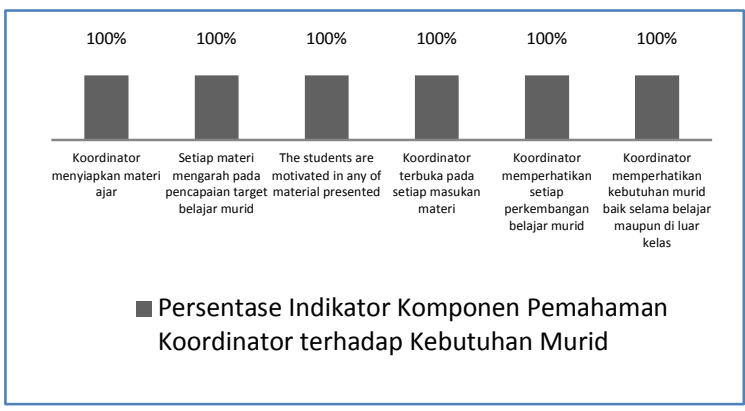

Gambar 6. Grafik Persentase Indikator Komponen Pemahaman Koordinator terhadap Kebutuhan Murid

Setiap materi yang disajikan sudah mengarah pada pencapaian target belajar. Setiap materi yang disajikan membuat murid termotivasi. Koordinator kelas terbuka menerima masukan materi dari murid. Koordinator juga memperhatikan kebutuhan di luar pembelajaran dan siap mendapatkan penilaian dari murid. Murid mengisi lembar feedback setiap minggu. Feedback adalah bukti penilaian murid terhadap tim guru yang berguna sebagai bahan evaluasi dan perbaikan.

Keefektifan Pengorganisasian Program Pembelajaran BIPA di Lembaga Kursus BIPA Kota Yogyakarta

Aspek pengorganisasian program pembelajaran BIPA diperoleh dari data hasil kualitatif yang menunjukkan kriteria "sangat efektif". Hal tersebut dikuatkan oleh pencapaian data hasil kuantitatif yang menunjukkan kriteria "sangat efektif". Pencapaian aspek pengorganisasian program pembelajaran BIPA menunjukkan pencapaian $99 \%$.

Aspek pengorganisasian program didukung oleh enam capaian komponen yaitu pengelolaan guru yang mencapai $100 \%$; pengelolaan jadwal belajar dan data murid yang mencapai $100 \%$; pengelolaan alat dan media pembelajaran yang mencapai $100 \%$; keberadaan dokumen jadwal belajar yang mencapai $100 \%$; keberadaan dokumen data murid yang mencapai $100 \%$; pengorganisasian pembelajaran yang mencapai $98 \%$.

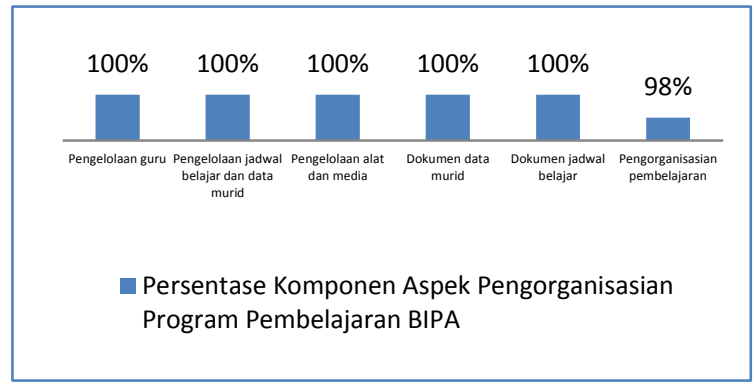

Gambar 7. Grafik Persentase Komponen Aspek Pengorganisasian Program Pembelajaran BIPA

Pengelolaan guru sudah dilaksanakan dengan tepat sesuai dengan kemampuan dengan capaian 100\%. Pengelolaan guru juga sudah tepat sesuai kemampuan guru tersebut mencapai $100 \%$.

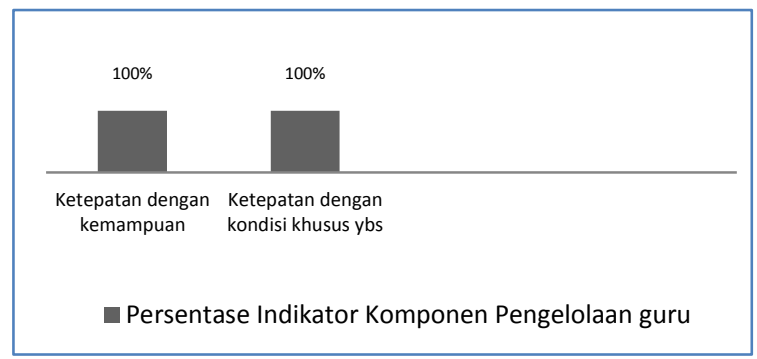

Gambar 8. Grafik Indikator Komponen Pengelolaan Guru

Beberapa hal yang sudah dilaksanakan lembaga untuk pengelolaan guru adalah setiap guru mendapatkan pelatihan untuk semua materi di setiap level; setiap guru mendapatkan pelatihan sebagai koordinator kelas; setiap guru ditempatkan pada komposisi kelas yang tepat; setiap guru menjalani proses pelatihan pada waktu yang sama. Berdasarkan data hasil wawancara dengan kepala bagian pengajaran untuk dapat menguasai teknik dan metode mengajar sesuai dengan program yang diselenggarakan lembaga, pelatihan calon guru dilaksanakan maksimal 1 tahun.

Pengelolaan guru juga dilaksanakan dengan memperhatikan indikator ketepatan dengan kondisi yang. Pemenuhan indikator ini dilakukan dengan guru yang mengajar sehat jasmani dan rohani; guru mengajar sesuai dengan kesanggupan 
mengajar; guru mendapatkan hak-haknya ketika dalam kondisi khusus (hamil, sakit, ijin khusus); guru mendapatkan dukungan dari lembaga saat melaksanakan tanggung jawab mengajarnya. Berdasarkan data hasil wawancara dengan kepala bagian pengajaran kondisi dan stamina yang prima sangat penting untuk menunjang pelayanan dan tugas mengajar yang profesional.

Pengelolaan jadwal belajar dan ruang kelas sudah memenuhi kriteria. Staf penjadwal menentukan jadwal berdasarkan permintaan murid, murid mendapatkan komposisi guru yang sesuai dengan kebutuhan belajarnya, ruang kelas rapi dan bersih, penentuan ruang kelas sesuai keadaan murid, penentuan ruang kelas sesuai materi yang disajikan, adanya rotasi kelas. Indikator menentukan jadwal belajar dan ruang kelas mencapai rata-rata $100 \%$. Berkaitan dengan jam belajar, Buscato (1997, p. 4) dalam penelitiannya menyebutkan bahwa"A two-hour session every other day is recommended for all classes. Alonger session gives ample time for everyone to interact and to share reflections, observations, insights and new items. The break every other day provides the opportunity for students to do assignment and write their reflections.

Komponen pengelolaan alat dan media pembelajaran mencakup ketersediaan alat dan media mencapai $100 \%$; penataan alat dan media mencapai $100 \%$; dan ketepatan penggunaan alat dan media mencapai $100 \%$.

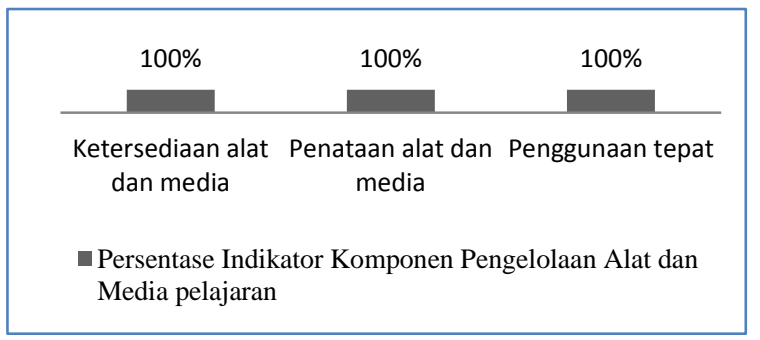

Gambar 9. Grafik Persentase Indikator Komponen Pengelolaan Alat dan Media

Kriteria ketersediaan alat dan media sudah terpenuhi dengan ditandai beberapa hal yang meliputi alat belajar berupa papan tulis, penghapus, dan spidol tersedia di setiap ruang; tersedia media belajar yang bervariasi; media belajar bisa digunakan untuk beragam materi; media belajar berkualitas dan terkini. Penataan alat dan media belajar dilakukan dengan menata alat dan media di dalam rak penyimpanan khusus, tersusun rapi, tidak rawan rusak, dan mudah diambil oleh guru.

Keberadaan dokumen data murid sangat penting untuk keberhasilan proses pengorganisasian program. Dokumen data murid sudah memuat nama murid mencapai $100 \%$; asal negara mencapai $100 \%$; tujuan pembelajaran mencapai $100 \%$; kemampuan awal mencapai $100 \%$; keterampilan awal mencapai $100 \%$; waktu belajar mencapai 100\%; dan topik yang akan dipelajari mencapai $88 \%$.

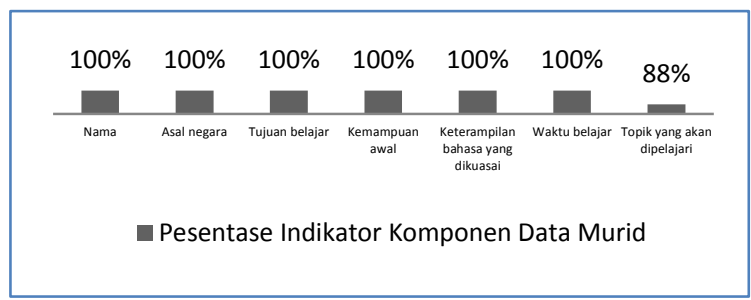

Gambar 10. Grafik Persentase Indikator Komponen Data Murid

Dokumen pengorganisasian program selanjutnya yang dicermati adalah keberadaan jadwal belajar. Indikator keberhasilan yang dipersyaratkan adalah nama murid mencapai 100\%; nama guru mencapai $100 \%$; waktu belajar mencapai $100 \%$; ruang kelas mencapai $100 \%$.

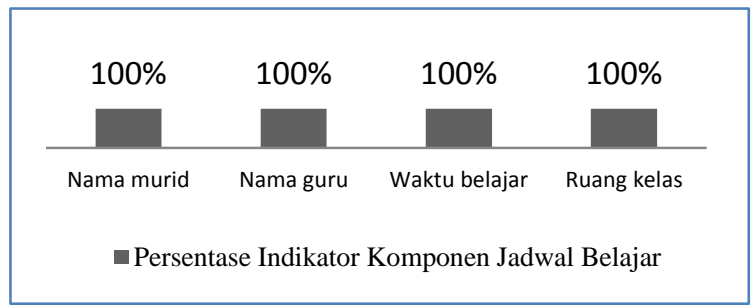

Gambar 11. Grafik Persentase Indikator Komponen Jadwal Belajar

Berdasarkan data kuantitatif yang diperoleh melalui angket murid aspek pengorganisasian program pembelajaran sudah mencapai rata-rata 98\%". Indikator yang dipersyaratkan pada komponen ini adalah waktu belajar sesuai kesepakatan murid mencapai 100\%; koordinasi tim guru terlihat selama pembelajaran mencapai $100 \%$; 
komposisi tim guru sesuai bobot materi mencapai $100 \%$; sumber belajar sesuai materi ajar $88 \%$.

\begin{tabular}{|cccc|}
\hline $100 \%$ & $100 \%$ & $100 \%$ & $88 \%$ \\
\hline $\begin{array}{l}\text { Waktu belajar sesuai } \\
\text { kesepakatan }\end{array}$ & $\begin{array}{c}\text { koordinasi tim guru } \\
\text { terlihat }\end{array}$ & $\begin{array}{c}\text { Komposisi tim guru } \\
\text { sesuai bobot materi }\end{array}$ & $\begin{array}{c}\text { Sumber belajar sesuai } \\
\text { materi ajar }\end{array}$ \\
& & & \\
& Persentase Indikator Komponen Pengorganisasian \\
Pembelajaran & & \\
\hline
\end{tabular}

Gambar 12. Grafik Persentase Indikator Komponen Pengorganisasian Pembelajaran

Selama pembelajaran koordinasi antartim guru dirasakan oleh murid. Hasil ini didukung oleh data wawancara koordinator kelas bahwa koordinasi antartim dimulai saat tim guru mengetahui hal-hal yang termuat dalam personal detail murid sehingga murid tidak harus mengulang informasi tersebut kepada setiap guru yang mengajarnya. Termasuk juga ketika tim guru memahami latar belakang kemampuan bahasa murid. Hal ini penting sebagai informasi guru, karena semakin banyak bahasa asing yang sudah dikuasai murid, semakin mudah murid belajar bahasa target (bahasa Indonesia). Pengalaman belajar akan mempengaruhi motivasi belajar yang sesungguhnya. Hal ini seperti yang diungkapkan oleh Diamantatou \& Hawes, (2016, p. 101) "pedagogical implications of negative past learning experiences must be considered when attempting to activate students and to increase their motivation".

Keefektifan Pelaksanaan Program Pembelajaran BIPA di Lembaga Kursus BIPA Kota Yogyakarta

Aspek pelaksanaan program pembelajaran BIPA yang diperoleh dari data hasil kualitatif menunjukkan kriteria "sangat efektif". Hal tersebut dikuatkan oleh pencapaian data hasil kuantitatif yang menunjukkan kriteria "sangat efektif". Aspek pelaksanaan program BIPA menunjukkan kriteria "sangat efektif" dengan pencapaian 93\%.

Pelaksanaan program pembelajaran BIPA didukung oleh 12 capaian kegiatan yaitu keberadaan dokumen desain silabus yang mencapai rata-rata $80 \%$; buku ajar yang mencapai rata-rata $97 \%$; bank soal yang mencapai rata-rata 95\%. Dilanjutkan dengan pengamatan terhadap kegiatan awal pembelajaran yang mencapai ratarata 95\%; pelaksanaan kegiatan pembelajaran mencapai rata-rata $87 \%$; pengelolaan interaksi kelas mencapai rata-rata 91\%; sikap guru mencapai rata-rata $99 \%$; evaluasi proses dan hasil mencapai rata-rata 89\%; kesan umum proses pembelajaran mencapai rata-rata 91\%. Capaian selanjutnya diperoleh dari data angket yaitu proses pembelajaran yang mencapai $94 \%$; kualitas guru yang mencapai 98\%; dan kondisi ruang yang mencapai $100 \%$.

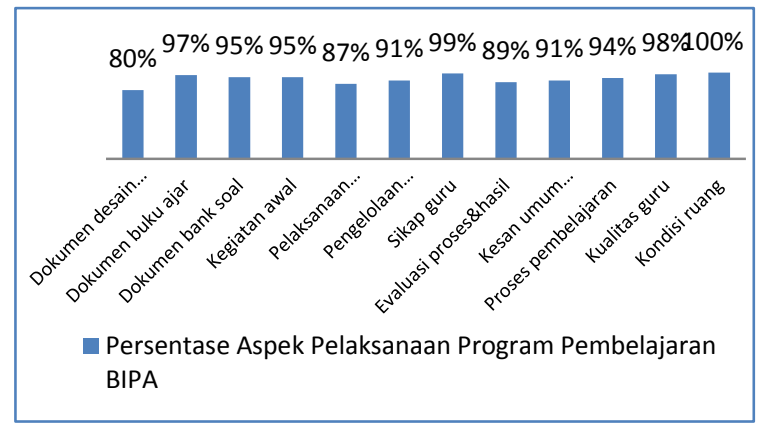

Gambar 13. Grafik Persentase Pelaksanaan Program Pembelajaran BIPA

Komponen desain silabus yang harus ada mencakup identitas murid yang mencapai $100 \%$; nama koordinator dan tim guru yang mencapai $100 \%$; waktu belajar yang mencapai $86 \%$; nama guru yang mengajar mencapai $86 \%$; topik yang dikehendaki mencapai $100 \%$; skenario pengajaran mencapai $84 \%$; laporan mengajar yang mencapai $66 \%$; komentar guru yang mencapai $72 \%$; tulisan dapat dibaca mencapai $72 \%$; bahasa komunikatif mencapai $77 \%$.

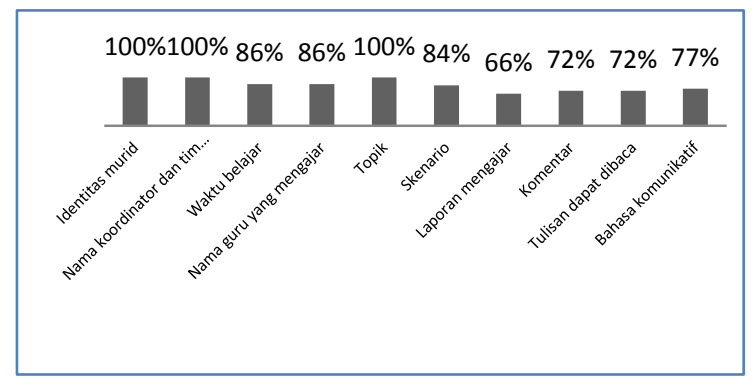

Gambar 14. Grafik Persentase Indikator Desain Silabus 
Dokumen pelaksanaan pengajaran selanjutnya berupa buku ajar. Buku ajar yang dicermati adalah keseluruhan buku ajar dari level beginner-advance. Materi susudah disajikan dari tingkatan mudah ke sulit. Indikator ini mencapai $100 \%$. Penggunaan bahasa target dalam buku ajar mencapai $91 \%$. Variasi soal mencapai 100\%. Variasi bentuk teks mencapai 100\%. Daftar kosakata mencapai 93\%. Catatan budaya mencapai $100 \%$.

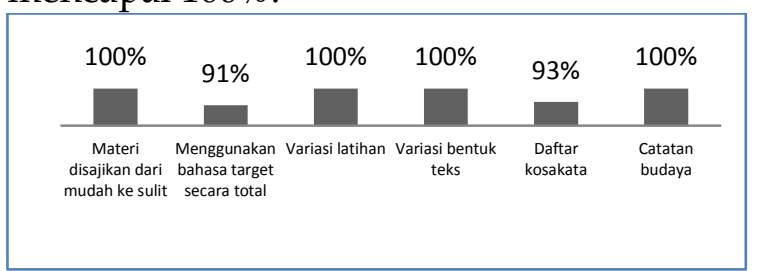

Gambar 15. Grafik Persentase Indikator Komponen Buku Ajar

Menurut keterangan dari kepala bagian pengajaran, bahasa Inggris digunakan dalam kalimat perintah pada latihan soal dan terjemahan daftar kosakata. Hal tersebut dimaksudkan agar murid lebih mudah memahami aktivitas yang harus dilakukan untuk mengerjakan soal-soal di buku ajar. Selebihnya, jika latihan soal tersebut akan dikerjakan di rumah, murid bisa langsung memahami perintah soal yang dimaksud.

Komponen selanjutnya yang dicermati adalah bank soal. Bank soal sudah terdapat rumusan pertanyaan yang dinyatakan dengan jelas mencapai $100 \%$; terdapat variasi bentuk soal mencapai $100 \%$; tersedia kunci jawaban mencapai $100 \%$; terdapat pedoman penilaian mencapai $100 \%$; tersedia lembaar jawab mencapai $63 \%$.

\begin{tabular}{|ccccc|}
\hline $100 \%$ & $100 \%$ & $100 \%$ & $100 \%$ & $63 \%$ \\
\hline $\begin{array}{c}\text { Rumusan } \\
\text { Pertanyaan } \\
\text { jelas }\end{array}$ & $\begin{array}{c}\text { Variasi } \\
\text { bentuk soal }\end{array}$ & $\begin{array}{c}\text { Kunci } \\
\text { jawaban }\end{array}$ & $\begin{array}{c}\text { Pedoman } \\
\text { penilaian }\end{array}$ & $\begin{array}{c}\text { Lembar } \\
\text { jawab }\end{array}$ \\
& Persentase Indikator Komponen Bank Soal & \\
\hline
\end{tabular}

Gambar 16. Grafik Persentase Indikator Komponen Bank Soal

Soal-soal yang dimiliki lembaga digunakan sebagai placement test dan tes akhir. Tidak semua guru/koordinator kelas memberikan placement test kepada murid. Placement test bisa dilakukan tidak hanya dengan mengerjakan soal tetapi juga dengan langsung tes berbicara dalam bahasa Indonesia.

Kegiatan awal yang dilakukan guru untuk melaksanakan proses pembelajaran meliputi menyiapkan alat, media, dan sumber belajar mencapai rata-rata $100 \%$; menyiapkan tugas harian kelas mencapai rata-rata 88\%; menciptakan suasana yang hangat dan akrab mencapai 95\%.

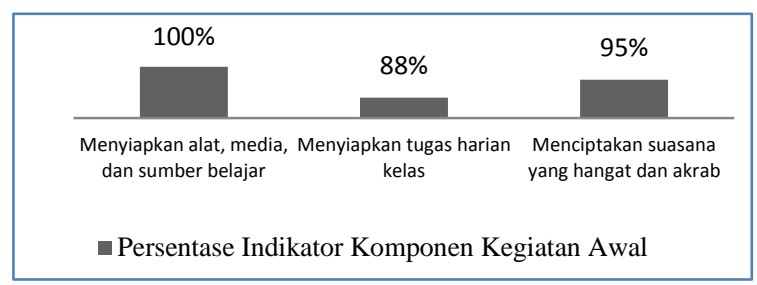

Gambar 17. Grafik Persentase Indikator Komponen Kegiatan Awal

Penyiapan alat, media, dan sumber belajar dilakukan guru dengan mengamati desain silabus. Tugas harian kelas meliputi mencermati desain silabus yang sudah ditulis koordinator kelas; mengecek ketersediaan alat tulis; mengecek kehadiran siswa; mengecek kebersihan ruangan dan perabotan kelas. Komponen kegiatan awal yang terakhir adalah menciptakan suasana hangat dan akrab. Hal-hal yang dilakukan oleh sebagian besar guru sudah memenuhi kriteria. Pembelajar bahasa kedua biasanya menghadapi stres saat memulai pembelajarannya. Jika hal ini terjadi, guru harus segera menyadarinya, mengobservasi bagaimana cara yang tepat untuk mengatasi stress murid, dan berusaha untuk mengelola stress menjadi hal yang positif. Seperti yang diungkapkan oleh Alqahtani \& Alajmi (2013, p. 170) "Language teacher have to equip themselves with what can be termed as a stress toolbox: awareness, observation, and management".

Komponen pelaksanaan kegiatan pembelajaran mencakup memulai kegiatan pembelajaran mencapai 79\%; melaksanakan strategi pembelajaran sesuai dengan tujuan siswa, situasi, dan lingkungan mencapai $80 \%$; menggunakan alat bantu pembelajaran yang sesuai mencapai $76 \%$; memantabkan penguasaan materi pembelajaran mencapai 95\%; melaksanakan kegiatan 
pembelajaran dengan urutan yang logis mencapai 94\%; dan mengelola waktu pembelajaran dengan tepat dan efisien mencapai $100 \%$.

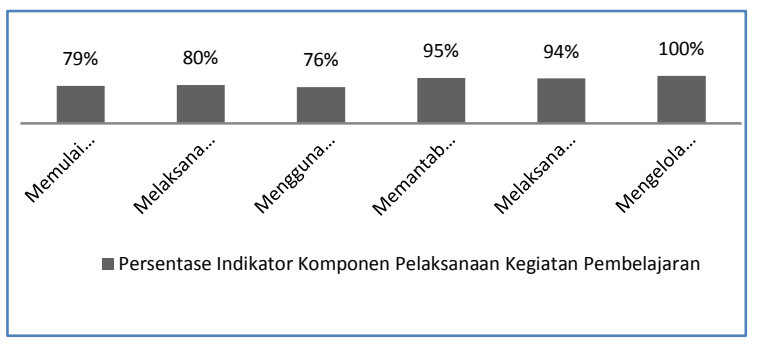

Gambar 18. Grafik Persentase Indikator Komponen Pelaksanaan Kegiatan Pembelajaran

Guru memulai kegiatan pembelajaran dengan mengucapkan salam. Guru bertanya menggunakan struktur yang sudah dipelajari sebelumnya. Hal ini dimaksudkan untuk mencairkan suasana dan sekaligus sebagai kesempatan guru melihat kemampuan penguasaan konsep sebelumnya. Hal ini penting dilakukan, menurut keterangan dari guru tahap ini adalah tahap penting untuk memastikan apa yang hendak dilakukan guru pada sesi itu, bahwa materi bisa dilanjutkan atau hanya melakukan pengulangan.

Indikator selanjutnya adalah melaksanakan strategi pembelajaran sesuai dengan tujuan, siswa, situasi, dan lingkungan. Guru melaksanakan rambu-rambu pengajaran yang sudah didesain oleh koordinator kelas. Pelaksanaan pembelajaran yang menggunakan alat bantu (media) pembelajaran yang sesuai dengan tujuan, siswa, situasi, dan lingkungan.

Pemantaban penguasaan materi pembelajaran telah dilakukan dengan mengulang kembali konsep dengan berbagai teknik, seperti bercerita dari gambar, membuat kalimat, role play percakapan, dan mengerjakan latihan soal. Materi disajikan dari mudah ke sukar, berkaitan satu sama lain, bermuara pada satu kesimpulan, dan ditindaklanjuti dengan PR/ tugas-tugas pada akhir pelajaran.

Waktu pembelajaran telah dikelola dengan efisien. Menurut keterangan kepala bagian pengajaran dan guru di setiap sesi terdapat empat tahapan proses pembelajaran yang harus dilalui, yaitu pengenalan konsep, melatihkan, membawa murid ke situasi, dan pemantaban.

Komponen selanjutnya adalah guru mengelola interaksi kelas. Hal ini dilakukan dengan memberikan petunjuk dan penjelasan yang berkaitan dengan isi pelajaran mencapai 93\%; menanggapi pertanyaan dan respon siswa mencapai $85 \%$; menggunakan ekspresi lisan, tertulis, dan gerak badan mencapai 100\%; memberikan kesempatan siswa berpraktek mencapai $93 \%$.

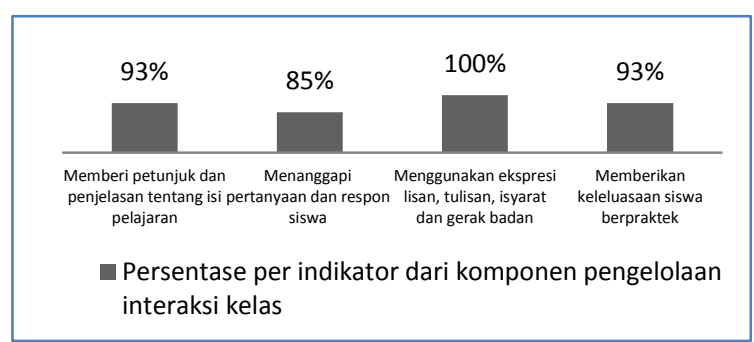

Gambar 19. Grafik Persentase Indikator Komponen Pengelolaan Interaksi Kelas

Interaksi kelas telah dikelola dengan memberikan petunjuk dan penjelasan yang berkaitan dengan isi pelajaran. Kegiatan ini antara lain dilakukan pada awal sesi belajar oleh koordinator kelas, pada awal mula tema baru oleh guru, dan atau pada akhir sesi setiap pelajaran untuk menegaskan kembali tujuan pembelajaran yang akan dicapai. Interaksi kelas telah dikelola dengan menanggapi pertanyaan dan respon siswa. Berdasarkan pengamatan pada proses KBM guru paling banyak menggali respon atau pertanyaan siswa selama pembelajaran berlangsung dan memberikan balikan kepada siswa. Guru menggunakan interaksi lisan, tulisan, isyarat, dan gerak badan. Berdasarkan pengamatan dan wawancara dengan guru, ketika murid tidak paham pada perintah/ penjelasan dari gu$\mathrm{ru}$, guru bisa menjelaskan secara lisan, tulisan, isyarat, ataupun gerak badan. Hal ini dilakukan sebagai usaha meminimalisir/ meniadakan penggunaan bahasa Inggris untuk menjelaskan konsep.

Komponen selanjutnya adalah sikap guru. Capaian ini didukung dengan kegi- 
atan mengembangkan hubungan antarpribadi yang sehat dan serasi dengan capaian 100\%; menunjukkan kegairahan mengajar mencapai $100 \%$; membantu siswa menumbuhkan kepercayaan diri mencapai 98\%. Guru sudah profesional dalam menjalankan tugas mengajarnya. Hal ini nampak ketika guru disiplin memulai dan mengakhiri pembelajaran, kualitas proses pembelajaran, dan balikan sikap murid kepada guru.

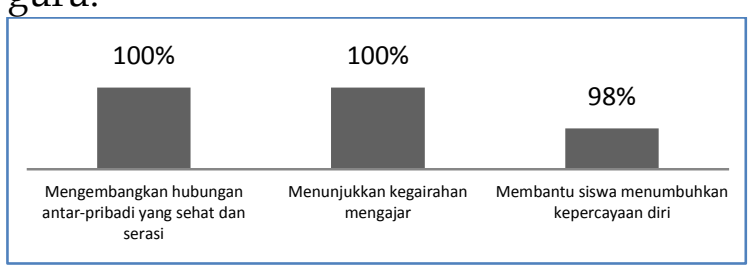

Gambar 20. Grafik Persentase Indikator Komponen Sikap Guru

Pelaksanaan evaluasi pada kursus bahasa terdiri dari evaluasi proses yang mencapai $97 \%$ dan evaluasi hasil yang mencapai $84 \%$.

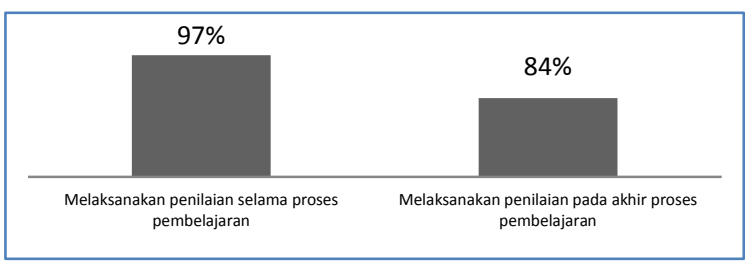

Gambar 21. Grafik Persentase Indikator Komponen Evaluasi Proses dan Hasil Belajar

Berdasarkan hasil pengamatan, evaluasi proses yang dilakukan oleh guru seperti meminta murid membuat kalimat dari gambar, bercerita, mengungkapkan kembali isi bacaan/dengaran, dan memberi kesempatan untuk berpraktek di luar kelas. Evaluasi hasil sering kali dilakukan dengan melakukan tes berbicara.

Komponen selanjutnya adalah kesan umum proses pembelajaran. Pelaksanaan pembelajaran BIPA secara umum didukung dengan indikator keefektifan proses pembelajaran mencapai 95\%; keefektifan siswa selama pembelajaran mencapai $100 \%$; ketertiban siswa mencapai 95\%; penampilan guru mencapai $100 \%$; penggunanaan bahasa target mencapai $77 \%$.

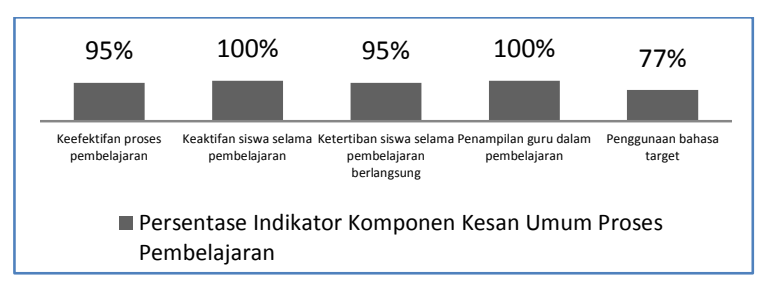

Gambar 22. Grafik Persentase Indikator Komponen Kesan Umum Pembelajaran

Ketika murid bertanya, guru mengusahakan berbagai cara agar tetap menjelaskan dalam bahasa target. Kroll \& Sunderman (2003, p.123) memberikan rekomendasi hal yang bisa dilakukan guru dalam hal ini, yaitu "Link the content of the foreign phrase to its mental concept rather than to its English translation. If possible, link it to pictorial object or action. The trick is to link the throught concept not with your own language, but with the language you are learning".

Menurut murid dari data angket, dalam proses pembelajaran murid sudah merasakan suasana yang hangat dan akrab yang mencapai $88 \%$; materi sudah disajikan dengan otentik dan komunikatif mencapai $88 \%$; materi sudah disajikan dari mudah ke sulit mencapai $100 \%$; media dan realia mampu mengkongkritkan konsep mencapai $88 \%$; buku ajar mempermudah belajar murid mencapai $88 \%$; media belajar sesuai dengan tujuannya mencapai $100 \%$.

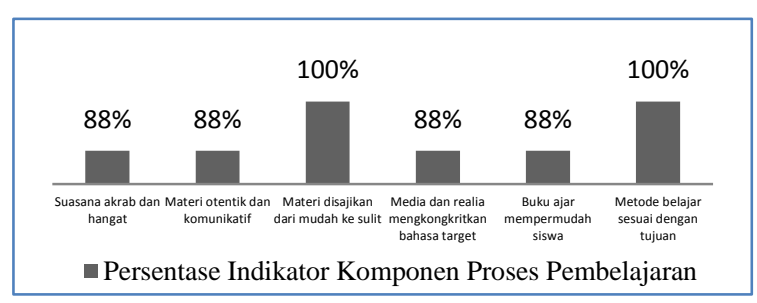

Gambar 23. Grafik Persentase Indikator Komponen Proses Pembelajaran

Pemahaman tentang sifat pembelajaran, khususnya bagi pembelajar bahasa kedua, akan membuat guru memahami kebutuhan belajar murid. Hal ini juga penting untuk menemukan materi yang sesuai dengan karakter murid, menemukan teknik yang tepat untuk mengajarkan materi tersebut. Seperti yang diungkapkan oleh Gurses \& Adiguzel (2013, p. 55) "The core of effective teaching is highly based on under- 
standing the nature of learning. Thus, figuring out the components included in an effective reading process, the behaviors displayed by an effective reader during this process, and how individuals learn a foreign language plays a crucial role for teaching reading in a foreign language".

Materi yang disajikan benar otentik dan komunikatif. Struktur-struktur bisa digunakan untuk berkomunikasi dengan masyarakat di Indonesia. Sesuai dengan yang diungkapkan oleh Buscato (1997, p. 5) “... the use of authentic materials and authentic language...".

Media dan realia telah sesuai untuk membantu mengkonkritkan konsep bahasa target. Media sangat penting digunakan untuk menimbulkan motivasi ekstrinsik. Oleh sebab itu, harapannya media yang dipilih dapat membuat siswa termotivasi belajar. Seperti yang diungkapkan oleh Ryan \& Desy (Saeed \& Zyngier, 2012, p.254) "Many of the class room activities that a teacher wants students to do are not necessarily in themselves interesting or enjoyable therefore, using more active and volitional forms of extrinsic motivation such as electronic media sources are effective strategies for successful teaching.

Kualitas guru dilihat dari indikator penggunaan bahasa target selama proses pembelajaran mencapai $100 \%$; antusias dan semangat mencapai $100 \%$; kejelasan menerangkan konsep bahasa mencapai 100\%; menjalin interaksi guru-murid mencapai $100 \%$; pemberian contoh yang tepat mencapai $100 \%$; pemberian kesempatan berpraktik mencapai 100\%; memberi koreksi yang membangun mencapai $100 \%$; persiapan guru baik mencapai $100 \%$; adanya variasi aktivitas mencapai $100 \%$.

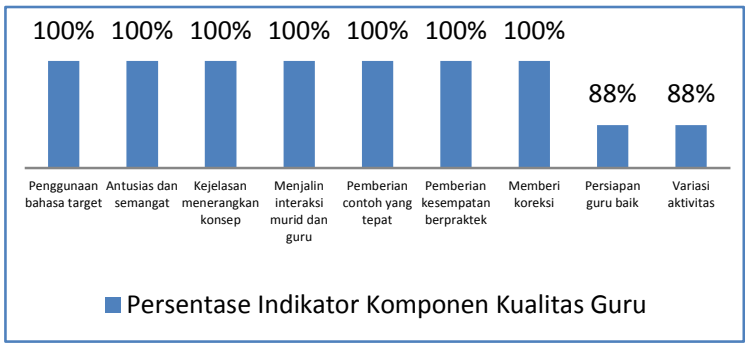

Gambar 24. Grafik Persentase Komponen Kualitas Guru
Kualitas guru selalu ditingkatkan dengan mengadakan seminar rutin tentang materi ajar, diskusi antarguru, dan pelatihan ke-BIPA-an baik di level nasional maupun internasional. Hal ini sesuai dengan hasil penelitian Suwarto \& Ishartiwi (2013, p. 7) yang mengatakan bahwa "Kualitas guru harus selalu ditingkatkan melalui pelatihan/ workshop yang berkelanjutan. Peningkatan kualitas SDM, terutama guruguru merupakan salah satu faktor penentu keberhasilan program".

Berdasarkan hasil angket, kondisi ruang/kelas di lembaga kursus BIPA bersih mencapai $100 \%$; rapi mencapai $100 \%$, pencahayaan baik mencapai $100 \%$; ventilasi/sirkulasi udara baik mencapai 100\%; lingkungan kondusif mencapai $100 \%$.

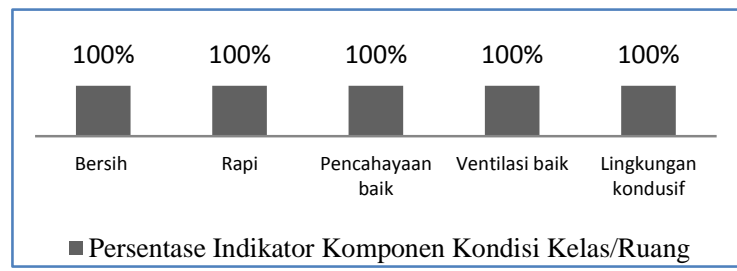

Gambar 25. Grafik Persentase Indikator Komponen Kondisi Ruang/Kelas

Ruang kelas terdiri dari satu meja besar, dua kursi, satu papan tulis, penghapus, jendela, dan AC. Selain ruang kelas ada juga ruang guru, ruang staf, kamar mandi, dapur, dan kios.

Keefektifan Pengawasan Program Pembelajaran BIPA di Lembaga Kursus BIPA Kota Yogyakarta

Aspek pengawasan program BIPA diperoleh dari data hasil kualitatif menunjukkan kriteria "sangat efektif" dengan capaian $86 \%$. Pengawasan program pembelajaran BIPA didukung oleh tujuh capaian yaitu keberadaan dokumen agenda kerja kepala bagian mencapai $100 \%$; program kegiatan mencapai rata-rata $100 \%$; laporan hasil pengawasan mencapai ratarata $100 \%$. Selanjutnya didukung oleh kegiatan pemantauan yang mencapai $54 \%$; supervisi mencapai $71 \%$; evaluasi mencapai $67 \%$; dan tindak lanjut mencapai $92 \%$. 


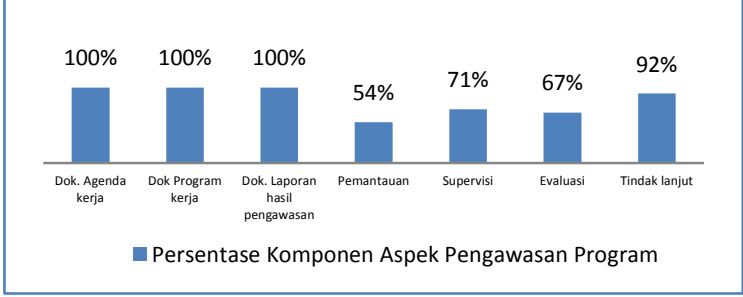

Gambar 26. Grafik Persentase Aspek Pengawasan Program Pembelajaran BIPA

Pengawasan program pembelajaran BIPA dilaksanakan utamanya oleh kepala bagian pengajaran. Pemantauan pada tahap perencanaan dilaksanakan dengan mengecek keseluruhan catatan dalam desain silabus. Pemantauan pada tahap penilaian dilaksanakan dengan mengecek hasil belajar murid melalui laporan lisan tentang kemajuan belajar murid yang disampaikan per minggu dan laporan tertulis berupa sertifikat belajar murid.

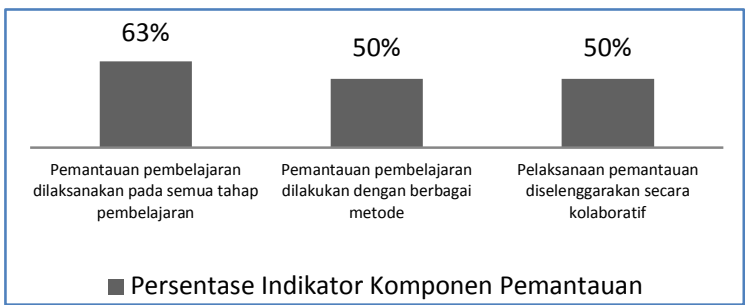

Gambar 27. Grafik Persentase Indikator Komponen Pemantauan

Komponen supervisi didukung oleh capaian kegiatan berikut supervisi pembelajaran dilaksanakan pada tahap perencanaan dan penilaian saja, atau perencanaan dan penilaian saja mencapai $63 \%$; supervisi pembelajaran dilaksanakan dengan berbagai metode mencapai $88 \%$. Pelaksanaan supervisi dilaksanakan secara kolaboratif yang mencapai $63 \%$. Supervisi dilakukan dengan memberi contoh/solusi yang harus dilakukan jika guru/koordinator menghadapi masalah untuk melaksanakan tugasnya, memberikan keterbukaan untuk konsultasi pribadi baik kepada kepala bagian maupun guru yang dianggap mampu membimbing, pelatihan guru, dan diskusi.

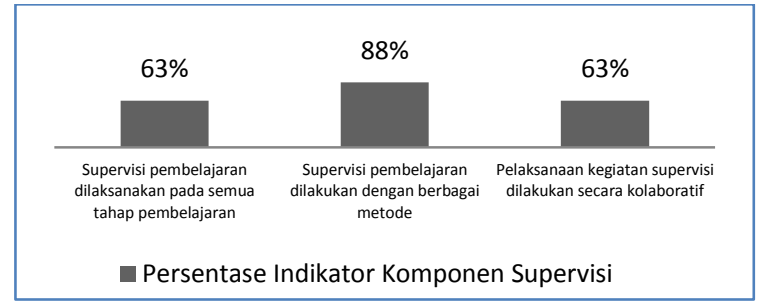

Gambar 28. . Grafik Persentase Indikator Komponen Supervisi

Komponen selanjutnya adalah melaksanakan evaluasi. Komponen ini didukung dengan tiga capaian kegiatan yaitu evaluasi dilaksanakan pada semua tahap mencapai $75 \%$; evaluasi dilaksanakan dengan berbagai metode mencapai $50 \%$; evaluasi dilaaksanakan menyeluruh pada kinerja guru mencapai $75 \%$.

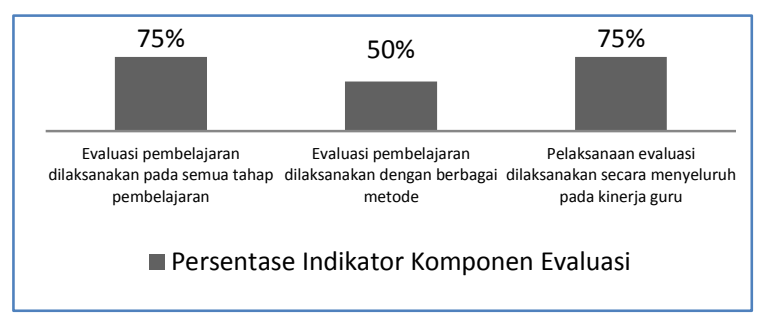

Gambar 29. Grafik Persentase Indikator Komponen Evaluasi

Hasil penelitian menunjukkan evaluasi program hanya dilaksanakan pada tahap perencanaan saja, pelaksanaan saja, atau evaluasi saja. Evaluasi dilaksanakan dengan membandingkan hasil akhir saja. Hasil akhir yang dimaksud adalah prestasi belajar murid. Jika prestasi belajar murid baik, artinya tim guru sudah melakukan tanggung jawabnya dengan baik pula.

Komponen selanjutnya adalah tindak lanjut kegiatan pengawasan. Hal ini dilakukan dengan melaporkan hasil pengawasan yang mencapai $100 \%$; memberikan reward $\mathcal{E}$ punishment mencapai $75 \%$; memberikan kesempatan guru mengikuti pelatihan mencapai $75 \%$.

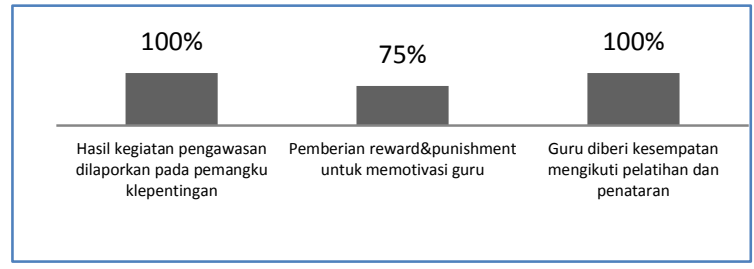

Gambar 30. Grafik Persentase Indikator Komponen Tindak Lanjut 
Laporan hasil pengawasan dilaporkan kepada guru dan koordinator kelas terkait dengan kinerja guru; kepada bagian kurikulum terkait dengan masukan materi/bahan ajar; kepada pengawas/direktur/manajer yang posisinya di atas kepala bagian pengajaran terkait dengan pencapaian target lembaga. Laporan ini dilaporkan setiap akhir tahun oleh kepala bagian pengajaran.

Semua guru sudah mendapatkan kesempatan yang sama untuk mengikuti pelatihan. Sudah sebaiknya setiap orang dalam organisasi selalu belajar dan memperbaharui ilmu pengetahuan agar pembelajaran berlangsung efektif dan masalahmasalah organisasi dapat dimininalisir. Seperti yang diungkapkan oleh Baah \& Tawiyah (2011, p. 10) "As the business environment continually changes, organisations increasingly need innovative ideas to stay ahead of competition. Learning therefore is viewed as the key factor that underpins organisational competitiveness".

Rekapitulasi hasil capaian manajemen program pembelajaran BIPA di lembaga kursus BIPA kota Yogyakarta adalah sebagai berikut.

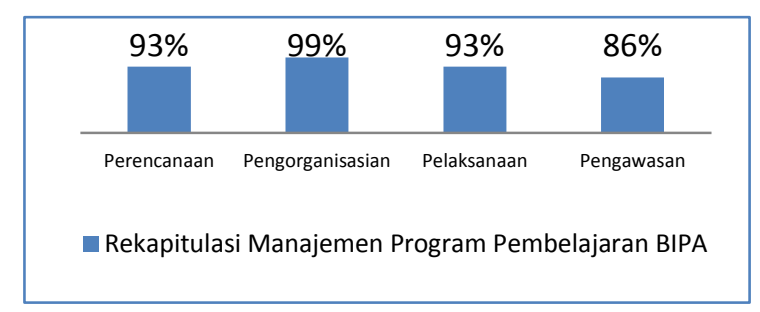

Gambar 31. Grafik Rekapitulasi Manajemen Program Pembelajaran BIPA

\section{Simpulan}

Bersarkan hasil penelitian dan pembahasan yang telah disampaikan, penelitian menghasilkan simpulan sebagai berikut. Tingkat ketercapaian manajemen program pembelajaran BIPA di lembaga kursus BIPA kota Yogyakarta adalah sebagai berikut. Perencanaan program pembelajaran BIPA menunjukkan pencapaian $93 \%$, dengan kriteria "sangat efektif". Aspek pengorganisasian program pembelajaran BIPA menunjukkan pencapaian $99 \%$ dengan kriteria "sangat efektif". Aspek pelaksana- an program pembelajaran BIPA mencapai 93\% dengan kriteria "sangat efektif". Aspek pengawasan program pembelajaran BIPA menunjukkan pencapaian $86 \%$, dengan kriteria "sangat efektif".

Saran-saran yang dapat disampaikan dari hasil penelitian dan simpulan adalah sebagi berikut. Secara umum telah diketahui bahwa pihak-pihak yang terlibat dalam manajemen sudah melaksanakan tugas dan tanggung jawab dengan optimal. Hal tersebut perlu dipertahankan dan ditingkatkan. Ditinjau dari manajemen program pembelajaran BIPA pada masing-masing lembaga. Pada aspek perencanaan program, akan lebih baik apabila tim kurikulum membuat komponen silabus dengan menyertakan indikator penilaian. Hal tersebut dilakukan agar koordinator kelas memiliki acuan prosedur dan jenis penilaian yang seharusnya dipakai untuk mengukur keberhasilan tujuan pembelajaran pada materi ajar. RPP (Lesson Plan) baku hendaknya dibuat per materi ajar, sehingga bisa benarbenar dimanfaatkan sebagai standar dalam pelatihan materi guru baru dan sekaligus menciptakan keselarasan model pengajaran antarguru. Pada perencanan pembelajaran hendaknya koordinator mengkomunikasikan rancangan pembelajarannya di awal kegiatan belajar kepada murid. Hal tersebut dilakukan sebagai bentuk konfirmasi agar seluruh rancangan belajar yang dibuat koordinator benar-benar merupakan keinginan dan kebutuhan belajar murid.

Pada aspek pengorganisasian guru, hendaknya lembaga lebih mencermati minat dan motivasi calon guru baru agar dapat selaras dengan kemampuan dan harapan lembaga.

Pada aspek pelaksanaan, hendaknya semua warga lembaga terutama pengajar menggunakan bahasa target secara total. Hal ini baik dilakukan dalam tuturan maupun buku ajar. Guru hendaknya menguasai teknik penggunaan media belajar/realia dan variasi penggunaannya sebelum mengaplikasikannya di hadapan murid. Hal tersebut dilakukan agar media belajar benarbenar berfungsi memperlancar proses belajar. 
Pada aspek pengawasan, hendaknya kepala bagian pengajaran melaksanakan pemantauan, supervisi, evaluasi, dan pelaporan hasil terhadap semua aspek manajemen secara berkesinambungan. Pihak lembaga hendaknya memperhatikan kebutuhan kepala bagian pengajaran terkait teori dan penerapan manajemen program dan evaluasi program dalam pembelajaran BIPA.

\section{Daftar Pustaka}

Arikunto, S. \& Jabar, C.S. (2009). Evaluasi program pendidikan. Jakarta: Bumi Aksara.

Alqahtani, A .A \& Alajmi, S.S. (2013). Psychological stress in language learning: A contempory view beyond teaching methods learning. Journal of education and practice, 6(5), 168-171

Baah, K. D \& Tawiyah, K. A. (2011). Influencing organisational behaviour through the application of learning theories. European Journal of Business and Management,3(11), 10-18.

Borich, G.D. (2007). Effective teaching method. (6 th ed). New Jersey: PrenticeHall Inc. Pearson Education Upper Saddler river.

Buscato, D. (1997). Proposed framework for a whole language program at the tertiary level. Guidelines: a periodical classroom language teachers, 19(2), 1-8.

Combs, P. H. \& Ahmed, M. (1985). Memerangi kemiskinan di pedesaan melalui pendidikan non-formal. (Terjemahan dari Yayasan Ilmu-ilmu Sosial). Jakarta: CV. Rajawali.

Daft, R. L. (1991). Management. (2th ed). New York: Rinehart and Winston, Inc.

Diamantatou, C. \& Hawes, T. (2016). Foreign language learning, motivation and the market economy. Journal of education and learning, 5(1), 95- 103.

Gurses, M.O. \& Adiguzel, O.C. (2013). The effect of strategy instruction based on the cognitive academic language learning approach over reading comprehension and strategy use. Journal of education and learning, 2(5), 55-68.

Keputusan Menteri. (2004). Keputusan Menteri Tenaga Kerja dan Transmigrasi RI Nomor 20, Tahun 2004, tentang Tata Cara Memperoleh Izin Mempekerjakan Tenaga Kerja Asing.

Kroll, J. \& Sunderman, G. (2003). Cognitive process in second language learners and bilinguals: The development of lexical and conceptual representations. The hanbook of second language acquisition, 5, 104-129.

Madya, S. (2013). Metodologi pengajaran bahasa: dari era prametode sampai era pascametode. UNY Press.

Miles, M.B., \& Huberman, A. M. (1994). An expanded sourcebook qualitative data analysis. Thousand Oaks. SAGE Publications.

Saeed, S. \& Zyngier, D. (2012). How motivation influences Student engagement: A qualitative case study.Journal of education and learning, 1(2), 252-267.

Suyitno, I. (2007). Pengembangan bahasa ajar bahasa Indonesia untuk penutur asing (BIPA) berdasarkan hasil analisis kebutuhan belajar. Wacana, 9, 62-78.

Suwarto, A. \& Ishartiwi. (2013). Persepsi warga sekolah tentang program percepatan belajar di SMP Pangudi Luhur Domenico Savio Semarang. Jurnal Akuntabilitas Manajemen Pendidikan, 1(1). Retrieved from http://journal.uny.ac.id/index.php/j amp/article/view/2308/1913

Toci, A. (2014). The importance of age in foreign language learning. Journal of education and practice, 5(2), 118-122.

Worthen, B.R. \& Sanders, J.R. (1981). Educational evaluation: Theory $\mathcal{E}$ Practise. Belmont California: Wordsworth Publishing Company Inc. 